911.5

\author{
- кртчян, . убер \\ ьвівський н ціон льний університет імені в н \\ вул. . орошенк , 41, м. ввів, 79000, кр їн
}

ведено основи методики геопросторового моделюв ння полів клім тичних елементів н підст ві мультирегресійного н лізу т методів геост тистики. я методик є перспективною щодо оптиміз ції т форм ліз ції технологій скл д ння клім тичних к рт, підвищення їхньої точності т н дійності.

лючові слов : геопросторове моделюв ння, клім тичні елементи, морфометричні х р ктеристики, геост тистичн інтерполяція.

лім т є в жливим компонентом природного середовищ, чинником впливу н рослинний покрив, грунти, водний режим л ндш фту. е зумовлює в жливе н укове т прикл дне зн чення к ртув ння клім тичних елементів як з собу відобр ження їхнього просторового розподілу в меж х певної території. лім тичні к рти м ють в жливе прикл дне зн чення, їх використовують у ході гроклім тичного р йонув ння, щоб визн чити оптим льні території для розміщення пос док і посівів сільськогоспод рських культур, під ч с пл нув ння розвитку туристично-рекре ційного комплексу, об'єктів, чутливих до клім тичних х р ктеристик ( еропорти, інші об'єкти тр нспортної т військової інфр структури) тощо. еред усіх клім тичних х р ктеристик чи не н йв жливіше екологічне, господ рське, медико-біологічне т інше зн чення м ють х р ктеристики темпер турного режиму т режиму тмосферних оп дів.

к відомо, розподіл клім тичних х р ктеристик зн чно з лежить від розподілу чинників, що вплив ють н клім т. дним із т ких в жливих чинників є рельєф земної поверхні, який суттєво вплив $є$ н темпер турний режим через фізично зумовлений вертик льний темпер турний гр дієнт, т кож через вплив н перерозподіл сонячної р ді ції і рухи повітряних м с. ідомий т кож вплив рельєфу н розподіл т режим тмосферних оп дів, що в помірному поясі н с мперед виявляється у збільшенні кількостей оп дів із підняттям угору, т кож у б р'єрному і депресивному ефект х [3].

еликий вплив рельєфу н розподіл клім тичних х р ктеристик, т кож широк доступність ост ннім ч сом дет льних цифрових д них про рельєф у формі цифрових моделей рельєфу ( ) д є змогу використовув ти т кі моделі для інтерполяції д них метеост нцій т створення к рт розподілу клім тичних елементів. р диційно т кі к pти скл д ли шляхом візу льної інтерполяції д них між метеост нціями, у ліпшому р зі - з ур хув нням вертик льних гр дієнтів клім тичних елементів. роте з появою ст ли широкодоступними і н були поширення методи інтерполяції, які грунтуються н форм льних, кількісних моделях просторової в рі ції феномен . жливою перев гою

(C) кртчян ., убер ., 2011 
т ких моделей $є$ відтворюв льність. відміну від використовув них у минулому м ну льних методик інтерполяції, які спир ються н суб'єктивні рішення к ртув льник , форм льні методи роблять процес інтерполяції зрозумілим і прозорим. рім того, з стосув ння форм льної методики з одн кових вихідних д них з вжди д є один і той же результ т, тоді як х р ктер к рти, скл деної м ну льно, суттєво з лежить від досвіду т інтуїції укл д льник .

р зі з стосув ння форм льних модельних методів інтерполяції існує змог вр хув ння впливу н цю х р ктеристику одр зу кількох чинників (як-от у вип дку з стосув ння моделі множинної регресії), ур хув ння нелінійних з лежностей (відомо, н прикл д, що кількість оп дів у гор х н йінтенсивніше зрост є до певної висоти, після якої інтенсивність зрост ння зменшується), т кож нелок льного х р ктеру впливу рельєфу н деякі клім тичні змінні.

и розробили методику втом тизов ної геопросторової інтерполяції клім тичних д них з використ нням інформ ції про рельєф, н веденої у формі цифрової моделі рельєфу ( ). я методик передб ч є дв послідовні ет пи. ерший ет п поляг є в побудові моделі множинної регресії, як кількісно відобр ж є з лежність між х р ктеристик ми рельєфу т клім тичною х р ктеристикою. другому ет пі моделюють просторовий розподіл з лишкових відхилень спостережених н метеост нціях зн чень клім тичної х р ктеристики від зн чень, передб чених регресійною моделлю. одібні 3 змістом методики інтерполяції д них розроблені й з стосов ні деякими з рубіжними дослідник ми $[5,6]$.

к ілюстр цію з стосув ння з пропонов ної методики змодельов но розподіл середньомісячних зн чень приземної темпер тури повітря з січень і липень 1985 i 1989 pp., т кож річних кількостей оп дів з 1961 і 1970 рр. оч ці д ні не відповід ють клім тичній нормі, вони д ють змогу перевірити ефективність з стосув ння методики в умов х відмінного синоптичного режиму.

ериторія дослідження охоплюв л 3 хідну ч стину кр їни в меж х ьвівської, к рп тської, в но- р нківської, олинської, ернопільської т ернівецької обл стей. к первинні використовув ли д ні метеост нцій території досліджень (усього 3336 метеост нцій з лежно від періоду спостережень т клім тичної х р ктеристики), оцифров ні з метеорологічних щорічників [2]. жерелом цифрової інформ ції про рельєф бул території досліджень, створен в ході д рної топогр фічної місії

ттлу 2000 p. і н явн у відкритому доступі (с йт http://srtm.usgs.gov). ервинн роздільн зд тність (розмір р стрового піксел ) цієї ст новить близько 90 м, проте їі було зменшено до 720 м з для зменшення н в нт ження н обчислюв льні ресурси в ході побудови регіон льних моделей.

оделюв ння геопросторового розподілу клім тичної х $\mathrm{p}$ ктеристики є з д чею моделюв ння відповідного просторового поля. е поле можн розкл сти н т кі скл дові:

$T(x, t)=\bar{T}(t)+T_{m}(x)+\varepsilon^{\prime}(x)+\varepsilon^{\prime \prime}$,

де $\bar{T}(x, t)$ - поле $з$ д ної клім тичної х р ктеристики; $T(t)$ - усереднений ч совий тренд (середне зн чення х р ктеристики з з д ний період для з д ної території); $T_{m}(x)$ - детермінов н в рі бельність, яку обчислюють з формулою, що вир ж є з лежність між цією х р ктеристикою т чинник ми рельєфу (регресійне рівняння); $\varepsilon^{\prime}(x)+\varepsilon^{\prime \prime}-з$ лишкове відхилення, причому $\varepsilon^{\prime}(x)-$ відхилення, яке є просторово ко- 
рельов ним; $\varepsilon^{\prime \prime}$ - некорельов не (вип дкове) відхилення. першому ет пі моделюв ння (регресійн модель) визн ч ють $T(t)$ т $T_{m}(x)$, н другому (геост тистичне моделюв ння) $-\varepsilon^{\prime}(x)$ т $\varepsilon^{\prime \prime}$.

ерший ет п моделюв ння скл д вся 3 т ких кроків: 1) визн чення х р ктеристик рельєфу, які є чинник ми впливу н клім тичний елемент і відігр в тимуть роль нез лежних змінних у моделі; 2) визн чення п р метрів цих змінних; 3) побудов т обчислення моделі множинної регресії.

ез лежними змінними потенційно можуть бути різні п р метри рельєфу, зокрем , н йз г льніші морфометричні пок зники: висот , іiі перш похідн (векторне поле похилів земної поверхні, компонент ми якого є ухили т експозиція) т другі похідні (три нез лежні кривини земної поверхні) [4], т кож пок зники ступеня розчленув ння земної поверхні.

ля визн чення н йбільш інформ тивних х р ктеристик рельєфу ми викон ли кореляційний н ліз з обчисленням коефіцієнт кореляції між певними х р ктеристик ми рельєфу т клім тичними х р ктеристик ми. еревірено зн чимість т ких чинників, як бсолютн висот, вертик льне розчленув ння поверхні (дисперсія зн чень висот у певному околі з д ного пункту), горизонт льн і вертик льн кривин, т кож ф ктор мезоекспозиції поверхні, визн чений як різниця середніх висот у двох протилежно н прямлених сектор х кол певного р діус .

ореляційний н ліз виявив відсутність зн чимої кореляції між лок льною кривиною поверхні т зн ченнями темпер тури і кількості оп дів. одо інших х р ктеристик рельєфу зн чення кореляції відрізнялось з лежно від клім тичного елемент т синоптичної х р ктеристики певного місяця чи року. прикл д, для річних кількостей оп дів з 1961 і 1970 рр. н йбільш зн чимими виявились т кі х р ктеристики рельєфу (у порядку зменшення зн чимості): вертик льне розчленув ння, ф ктор експозиції (з зимутом н $\mathrm{x}-$ д $\mathrm{x}$ ), бсолютн висот . ік во, що для обох з зн чених років вплив вертик льного розчленув ння н кількості оп дів виявився суттєво сильнішим, ніж вплив висоти: для 1961 р. зн чення критерію t (для 29 ступенів вільності) ст новило 4,33 для вертик льного розчленув ння і 2,75 для висоти, для 1970 р. (31 ступінь вільності) - 6,08 для вертик льного розчленув ння і лише 1,1 для висоти. мовірно, вертик льне розчленув ння рельєфу вплив $є$ н кількість оп дів через збільшення турбулентності повітряних м с і вплив н дин міку циклонічних систем.

ншим цік вим ф ктом $є$ те, що з восьми можливих зимутів н йбільш кореляція спостережен 3 зимутом $\mathrm{H}$ х- д $\mathrm{x}$, тобто н йбільш кількість оп дів вип д $€ \mathrm{H}$ території з північно-з хідною мезоекспозицією.

оефіцієнт множинної кореляції між сукупністю з зн чених чинників т річними кількостями оп дів виявився доволі високим: 0,93 для 1961 р. т 0,95 для 1970 р. е підтверджує те, що морфометричні пок зники можуть слугув ти добрими предиктор ми річних кількостей оп дів і бути використ ними у їхньому к ртув нні.

одо зв'язку між морфометричними т темпер турними пок зник ми, то було прон лізов но цей зв' язок для всіх місяців 1985 т 1989 pp. к і передб ч ли, н йтісніший зв'язок виявлений між середньомісячними темпер тур ми т бсолютною висотою. усі місяці цих двох років вплив бсолютної висоти був ст тистично зн чимим. роте інтенсивність цього впливу в різні місяці різн . йсильніше він виявлявся влітку (коефіцієнт кореляції $\mathrm{r}<-0,9$ ). січні 1985 р. г ст новив лише -0,12, в березні - -0,21. 1989 р. кореляція між бсолютною висотою і темпер турою т кож узимку бул сл б- 
шою, ніж улітку, проте й доволі високою (у січні - -0,67, в інші місяці - <-0,8). одібно змінюв вся й усереднений вертик льний темпер турний гр дієнт - у січні $1985 \mathrm{p}$. він ст новив лише $3,4^{\circ}$ н 100 м, у середньому з 1985 p. $-5,5^{\circ}$ н 100 м, тоді як 31989 p. - 6,6 $6^{\circ}$ н 100 м. зн чимо, що зим 1985 р. бул ном льно холодною (середня темпер тур січня н $1,5-6,0^{\circ}$, лютого - н $5-10^{\circ}$ нижч від норми). рім того, простежув лися ч сті зміни синоптичного режиму - під ч с різких похолод нь імовірно сильно виявлялись темпер турні інверсії, що відбилось н середньомісячних зн ченнях коефіцієнт кореляції т гр дієнт . е ж спостеріг ли і в березні, коли різко перев ж в нтициклон льний тип циркуляції. одноч с у лютому т березні 1989 р., коли перев ж л сух т ном льно тепл для цих місяців погод, вплив бсолютних висот н темпер туру був доволі високим $(\mathrm{r} \approx 0,9)$. е пояснюють добрим прогрів нням долин і знижень без снігового покриву сонцем. 1989 р. н йнижчий вертик льний гр дієнт темпер тури спостеріг ли в серпні $-4,4^{\circ}$ н 100 м. цьому місяці вир зно перев ж л циклон льн циркуляція, територією 3 ходу кр їни впродовж місяця переміщув лись тмосферні фронти т улоговини, тмосферний тиск був н йнижчим серед усіх місяців року. тже, причин зменшення впливу висоти н темпер туру в цьому місяці бул іншою - нівелюв ння темпер турних відмінностей у хм рну вітряну погоду.

еред інших пок зників рельєфу н йбільше н темпер туру вплинуло зн чення вертик льного розчленув ння рельєфу. ей вплив був неоднорідним у ч сі: н прикл д, у січні-березні 1985 р. він був дод тним (підвищення темпер тури зі збільшенням розчленув ння), в ці ж місяці 1989 р. - від’ємним. ояснити цю відмінність доволі скл дно.

кремо н лізув ли вплив мезоекспозиції з основним румб ми. есподів но цей вплив виявився доволі сл бким порівняно н віть із впливом експозиції н розподіл кількостей оп дів. ізниця експозиції по лінії південь-північ помітно корелюв л 3 розподілом темпер тур лише у січні-лютому 1989 р., коли з п нув ння сонячної погоди й відсутності снігового покриву спостеріг ли зн чну відмінність у н дходженні сонячної р ді ції н схили південної т північної експозицій. березні 1985 р. т грудні, січні й лютому 1989 р. схили східної експозиції були теплішими від схилів з хідної.

усі ці місяці перев ж л сух нтициклон льн погод . н вп ки, для квітня 1985 р., єдиного місяця, коли з хідні схили були помітно теплішими від східних, було х р ктерне різке перев ж ння циклон льного типу циркуляції (місяць м в н йнижче 3 дв досліджув ні роки середне зн чення тмосферного тиску). одо впливу кривини (випуклості-увігнутості), то він сл бко простежений лише в літні місяці (червень-серпень), коли ступінь його достовірності (зн чення ймовірності $p$ нульової гіпотези) ст новить $0,03-0,06$.

голосимо, що вплив більшості чинників є нелок льним, тобто н йбільш кореляція клім тичної х р ктеристики простежен не з х р ктеристикою рельєфу, виміряною безпосередньо у з д ному пункті (місцеположенні метеост нції), 3 х р ктеристикою, усередненою з певним околом цього пункту. е пов'яз не з тим, що вплив рельефу опосередков ний тмосферними синоптичними процес ми, які м ють певний х $\mathrm{p}$ ктерний м сшт б прояву. прикл д, з спостереженнями . ppi, середня висот в р діусі 8 км від місця розт шув ння дощомір є ліпшим предиктором річної кількості оп дів, ніж висот метеост нції [1]. е озн ч $є$, н прикл д, що визн чені з вертик льним гр дієнтом зн чення кількості оп дів для днищ вузьких долин будуть суттєво з ниженими, для вершин вузьких хребтів - з вищеними. н шому н лізі виявлено, зокрем , що 
вплив мезоекспозиції схилів н темпер турний режим був н йсильнішим у рухомому вікні р діусом 3,6 км, тоді як вплив н кількості оп дів вертик льного розчленув ння рухомому вікні р діусом 10 км, вплив н кількості оп дів ф ктор мезоекспозиції - у вікні р діусом 50-70 км.

рім н слідків впливу х р ктеристик рельєфу, режим темпер тур і оп дів х р ктеризують нез лежною від рельєфу в рі бельністю, н прикл д, поступовими змін ми темпер тур у широтному т меридіон льному н прям х. кі зміни доцільно моделюв ти 3 використ нням методів геост тистики. цьому р зі моделюють просторовий розподіл з лишкових відхилень зн чень клім тичних елементів від зн чень, перед6 чених регресійною моделлю. лишкові відхилення в пункт х розт шув ння метеост нцій визн ч ють шляхом віднім ння ре льних зн чень від зн чень, розр хов них 3 цією моделлю. ісля цього виконують інтерполяцію з лишкових відхилень, для чого використовують метод геост тистичної інтерполяції (крігінг).

еост тистичн інтерполяція ефективн лише в тому вип дку, коли є суттєвий зв'язок ( втокореляція) відст ні між пункт ми спостережень з відмінностями зн чень у цих пункт х. н шому вип дку це були зн чення з лишкових відхилень регресійної моделі. в'язок між різницею відхилень у точк х спостережень т відст нню між цими точк ми н зив ють в ріогр мою. снує низк критеріїв ефективності геост тистичної інтерполяції, зокрем - похибк інтерполяції в р зі перехресної перевірки т інформ ційний критерій Akaike. ш клім тичного елемент і певного періоду, з звич й, обернено пропорційн до кореляції з морфометричними пок зник ми.

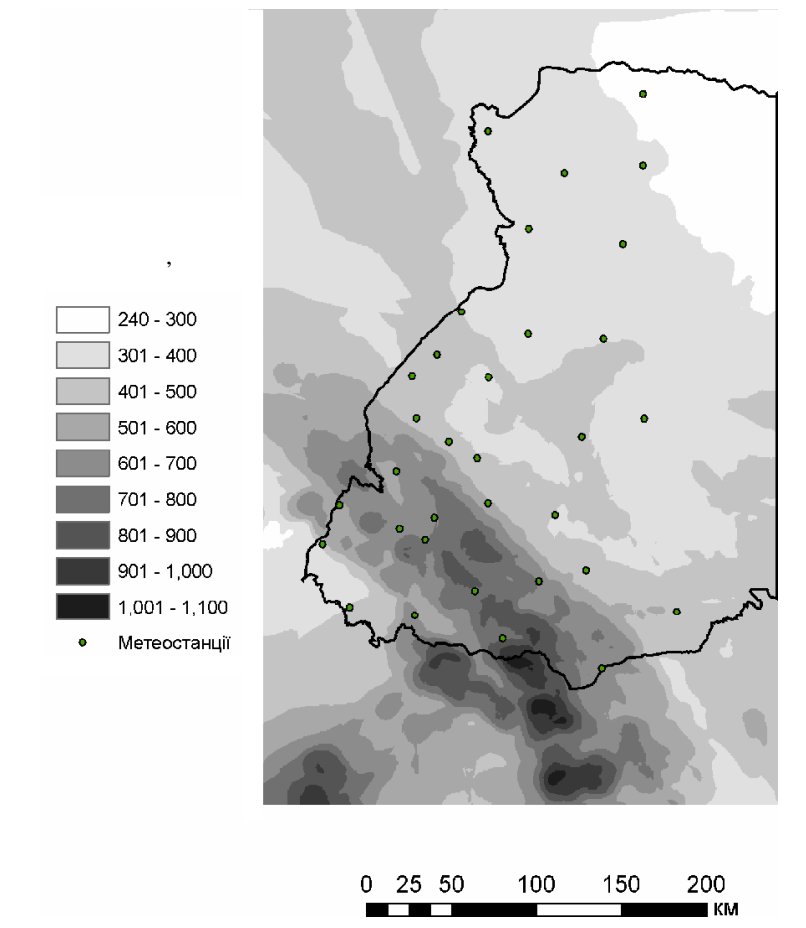

ис. 1. озподіл річної кількості тмосферних оп дів уз хідних регіон х кр їни, $1961 \mathrm{p}$. 
рис. 1-6 зобр жено отрим ні к рти розподілу річної кількості оп дів для 1961 і 1970 pp., т кож середньомісячних темпер тур для січня і липня 1985 і 1989 рр. для $з$ хідних регіонів кр їні. і к рти відобр ж ють вплив н клім тичні елементи х р ктеристик рельєфу, т нез лежні від рельєфу регіон льні відмінності.

кщо 3 мість річних т місячних д них використ ти усереднені д ні б г торічних спостережень, що х р ктеризують клім тичну норму, то можн отрим ти клім тичні к рти розподілу темпер тур т оп дів 3 б торічний період. Ю методику можн використовув ти й для створення к рт розподілу інших клім тичних змінних - трив лості вегет ційного періоду, н дходження сонячної р ді ції і $\mathrm{p}$ ді ційного б л нсу, сили вітрів тощо. опр вд, для цього можуть зн добитись інші п р метри рельєфу, інші зн чення $\mathrm{p}$ діус рухомого вікн т (можливо) інші модифік ції опис ної методики.
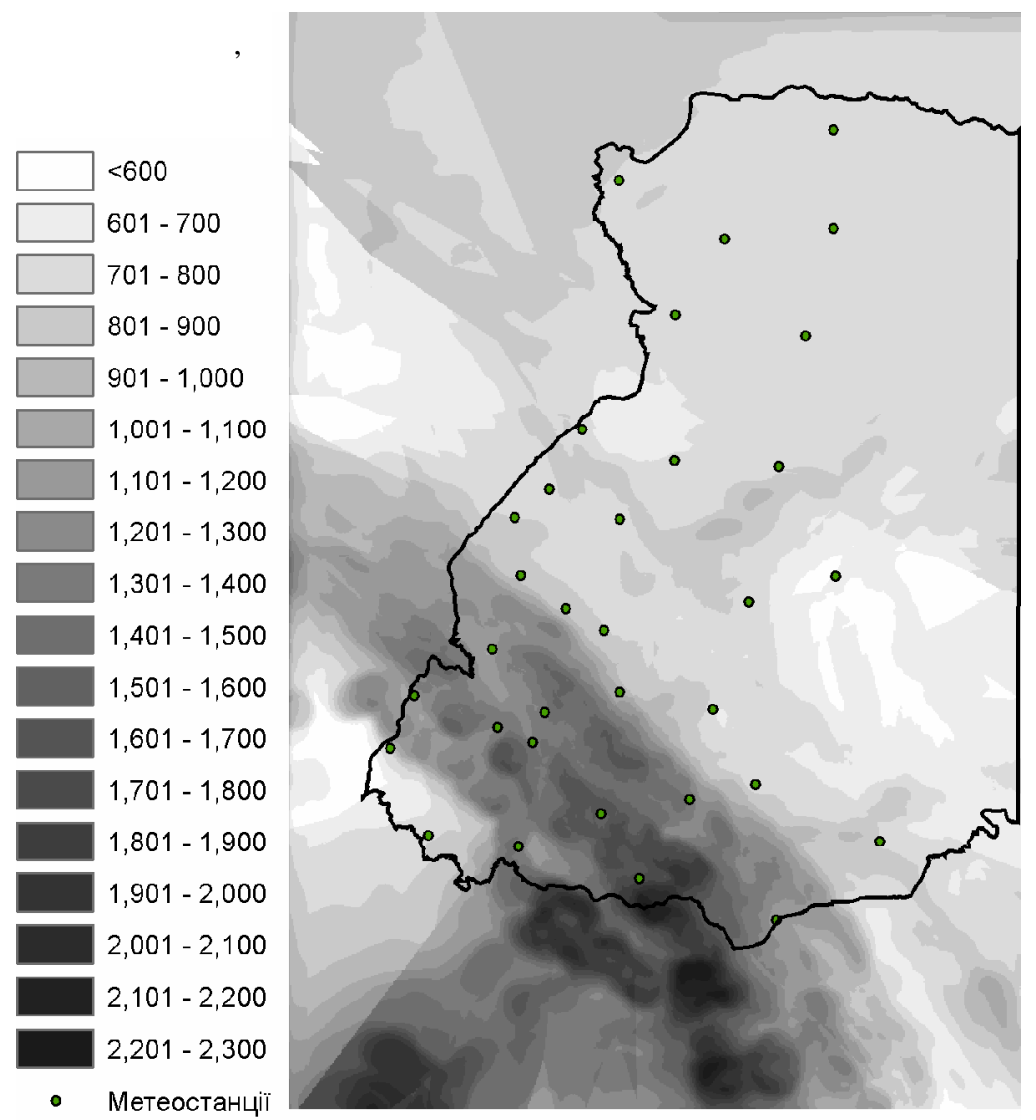

- Метеостанції

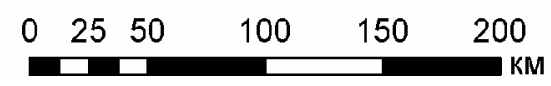

ис. 2. озподіл річної кількості тмосферних оп дів уз хідних регіон х кр їни, 1970 p. 


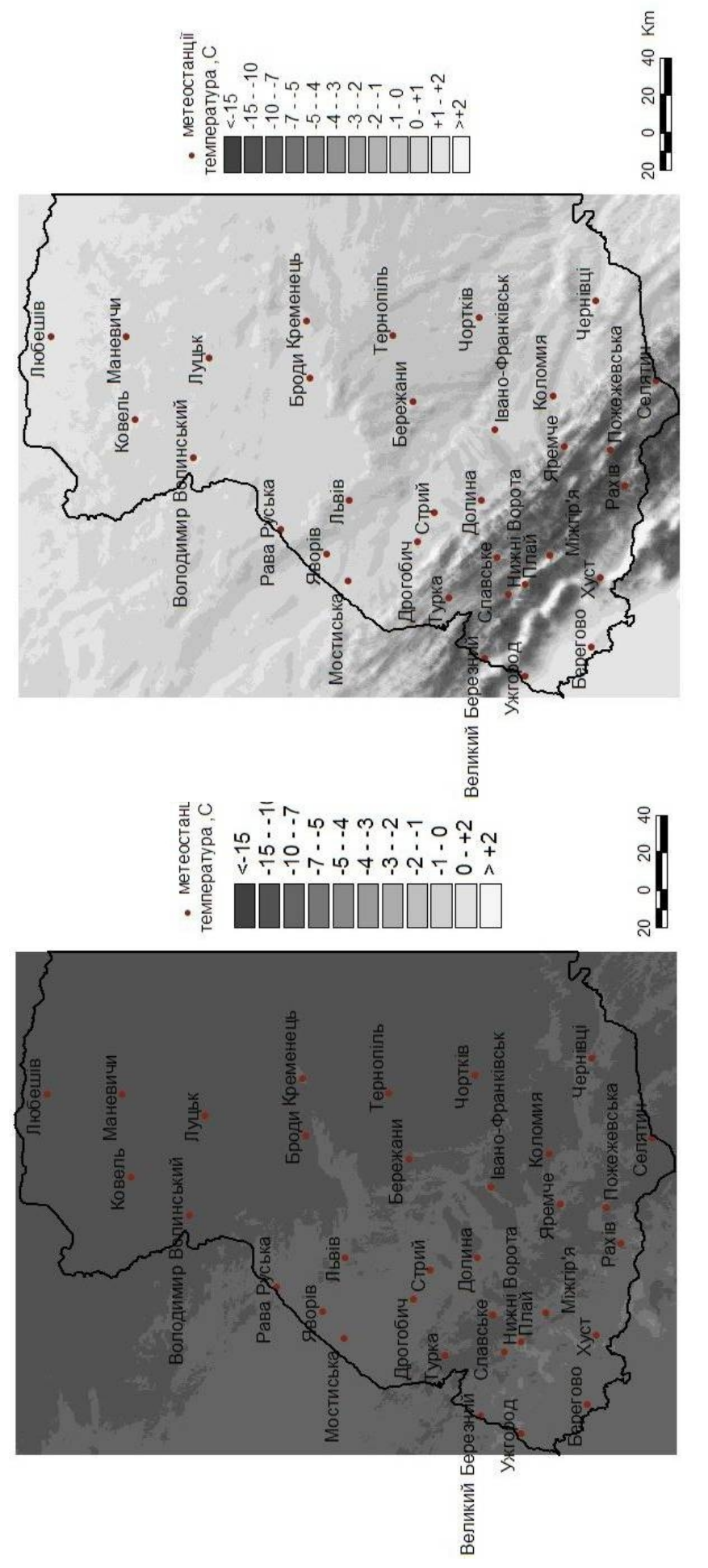

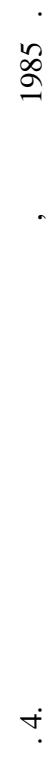

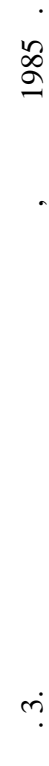




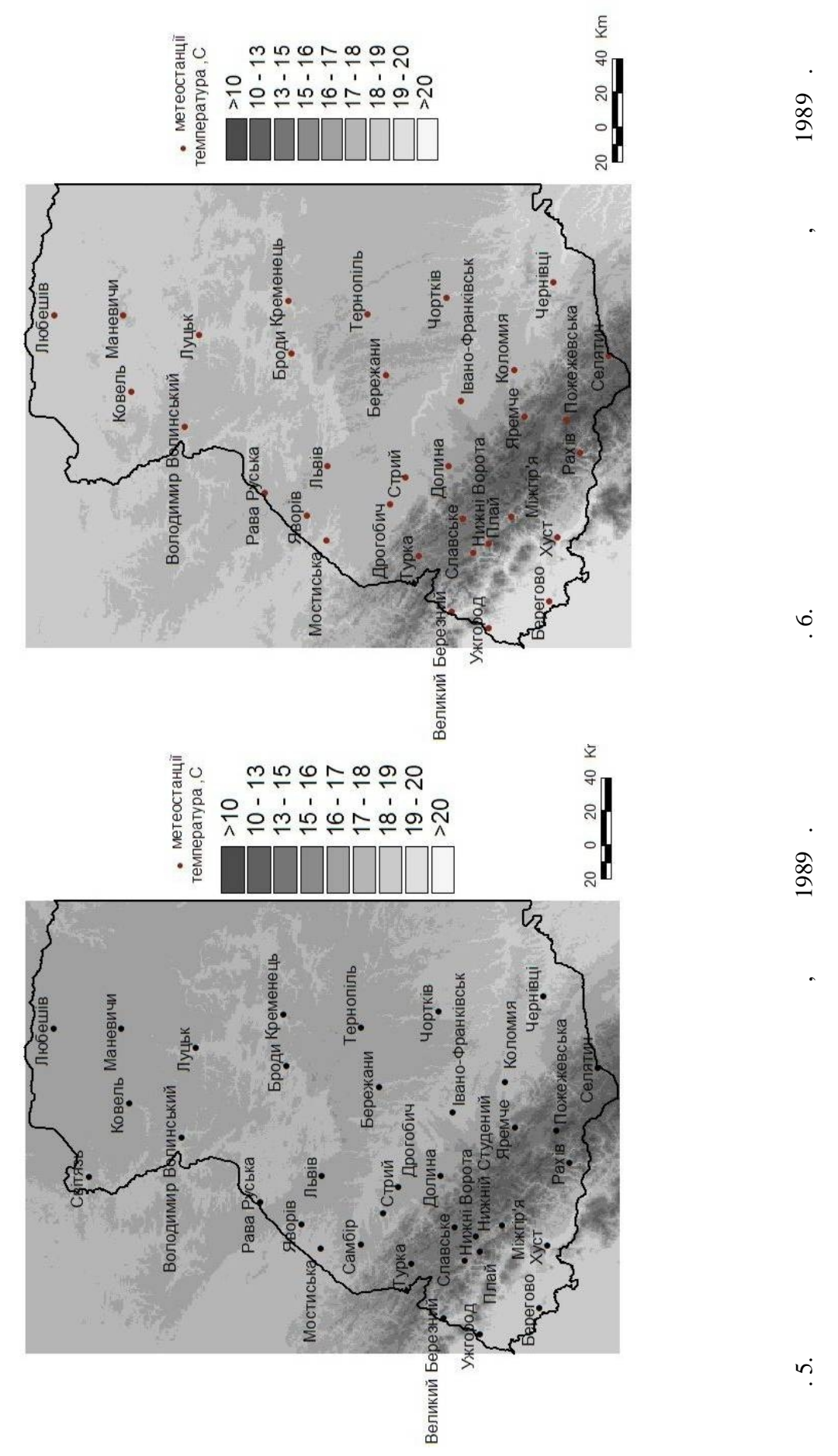


1. $р р и$. огод и клим т в гор х/ . рри. енингр д, 1984.

2. етеорологический ежемесячник / осуд рственный комитет бнинск, 1989. ып. 10, № 1-12, 1961, 1970, 1985, 1989.

3. ленев . . оздействие м крорельеф н клим т и л ндш фтные комплексы / . . ленев. вердловск, 1987.

4. ысуев . . изико-м тем тические основы л ндш фтоведения / . . ысуев. ., 2003. 175 с. 5. Hengl T., Heuvelink G., Rossiter D. About regression-kriging: From equations to case studies / T. Hengl, G. Heuvelink, D. Rossiter // Computers \& Geosciences. 2007. N33. P. 1301-1315.

6. Ustrnul Z. System informacji geograficznej jako narzedzie do konstrukcji cyfrowych map klimatycznych / Z. Ustrnul // Klimatyczne aspecty srodowiska geograficznego. Pod red. J. Trepinskiej i Z. Oleckiego. Krakow, 2006. P. 365-374.

\section{A METHOD FOR GEOSPATIAL MODELING AND MAPPING OF CLIMATIC CHARACTERISTICS FROM METEOSTATION OBSERVATION DATA}

\section{A. Mkrtchian, P. Shuber}

Ivan Franko National University of Lviv, . Doroshenko St., 41, UA - 79000 Lviv, Ukraine

In the paper the fundamentals of the method of geospatial modeling of climatic fields based on multiple regression analysis and geostatistics are given. This method is promising as a tool for the optimization and formalization of the climatic mapping techniques and the improvement of the precision and reliability of climatic maps.

Key words: geospatial modeling, climatic characteristics, land-surface parameters, geostatistical interpolation.

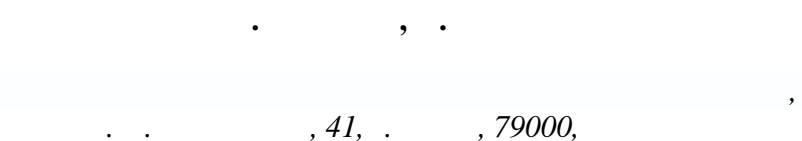

риведены основы методики геопростр нственного моделиров ния полей клим тических элементов н основе мультирегрессионного н лиз и методов геост тистики. нн я методик является перспективной для оптимиз ции и форм лиз ции технологий сост вления клим тических к рт, повышения их точности и н дежности.

лючевые слов : геопростр нственное моделиров ние, клим тические элементы, морфометрические $\mathrm{x}$ р ктеристики, геост тистическ я интерполяция.

т ття н дійшл до редколегії 22.01.2010 рийнят до друку 19.04.2010 